\title{
Competition Can Change a Lot: Striking Results Regarding Women from Rural Areas in Turkey
}

\author{
Bülent Gülçubuk
}

Department of Agricultural Economics, Faculty of Agriculture, Ankara University, Turkey

Copyright $(2016$ by authors, all rights reserved. Authors agree that this article remains permanently open access under the terms of the Creative Commons Attribution License 4.0 International License

\begin{abstract}
The Republic of Turkey Ministry of Food, Agriculture and Livestock has been organising a competition, whose title is "Women Farmers Contest" and which aims to promote social status of women who live in rural areas and are engaged in farming, to provide efficient knowledge, in Turkey since 2004. The aim of the competition is to evaluate the knowledge and performance of women farmers, to assess the outcomes of training-publications for these women, to raise self-confidence of these women, to raise consciousness of healthy nutrition and producing high quality crop, and to offer and increase entrepreneurship. The Competition awards prizes, which are cash money, loan support, tractor and other equipment supports, livestock and agricultural insurance to women, invite them at city, regional and national levels competition. The competition takes places among women farmers based in the rural areas of 81 cities in Turkey. Those who participates in in the final phase of the city, region and Turkey Competition answer various questions such as plant production, animal breeding, agricultural mechanisation, nutrition, child development, agricultural enterprise, agricultural organisation, family ownership management, and handcrafts. "Women Farmers Contest", which is a knowledge-based competition and has been organised among women based in rural areas since 2004, generates huge excitement and creates competition environment among women and families.
\end{abstract}

Keywords Rural Woman, Woman Farmer, Rural Turkey, Farmers Contest

\section{Introduction}

Women and children are considered the most disadvantageous ones in development literature. As a result of dominant discriminatory attitude which is practised in the following forms: any work done by women is accepted less valuable and less respectful than by men; these works are considered less "significant" in assessments, recordings across the country; women have more limited access to sources than men; women have less control over family income than men; women have lesser administrative and control position in public space, women suffer from disadvantageous positions and there is no change even they have higher status in the society. Women's share particularly in agricultural production and status in rural area in important in Turkey since the country has characteristics of agriculture society though they are decreasing. The level of women's shares and contribution is so important that it cannot be underestimated.

Decrease in agricultural income led men to leave agricultural sector and as a result to womenisation of agriculture. In addition to their services for their families, women in rural areas both maintain domestic production and join agricultural production. Women usually work in positions which require intense labour and have much more workload than men in small and medium sized enterprises. However, any work done by men is socially more prestigious and they earn more for same job. Women work usually in seasonal and part-time jobs, which are mainly based on domestic production, or in unpaid works. Thus, their income is spent usually for clothes, food, which are quickly consumed, in other words their work has no economic meaning (1).

In spite of the decrease in agricultural employment, it is still the sector that women employment is the highest. Women have higher level of joining labour force in rural areas than in urban areas. According to the Turkish Statistical Institute's figures; agriculture has $20.7 \%$ employment rate as regards to the total employment in Turkey. On the other hand, it is $31.7 \%$ for women and $14.5 \%$ for men in total agricultural employment. In other words, women employment in agricultural sector is 2.2 times higher than men employment. This fact reveals that any employment option other than agriculture in rural areas is usually for men and agriculture continues to be the destiny of women in these areas. Sectoral employment percentages in Turkey as follows: $20.7 \%$ in agriculture, $20 \%$ in industry, $7.2 \%$ is construction and $52.1 \%$ in service sector. Labour force participation rate is $51.1 \%$. The labour force participation rate for men is $71.2 \%$ while it is $31.4 \%$ for 
women. Women employment occupies the highest rate in agriculture in Turkey. Yet, $95.2 \%$ of these women in are work informally and are not registered with social security system. (2).

Women are usually "ignored" in statistics on women in rural areas, also there is an inclination that their work and production can be "ignored". For example, unpaid agricultural work or food production only for family or temporary works can be ignored. Those who directly participate in production and make big contributions to country's economy in rural areas are women. Furthermore, these same women work for free at home or in family's, relatives' field (3).

Most of the women working in rural areas have the status of unpaid family workers. Increasing women labour forces is, first and foremost, related to economic development and new investments, creation of new employment sectors. $79.7 \%$ of women who work in rural areas are unpaid family labour force. The percentage of women "employers" in rural areas is only $0.25 \%$ and it is too low. $15 \%$ women work for themselves. This fact is another proof that there are almost no "entrepreneur" women in the society. Another important phenomenon, which needs to be highlighted at this point, is that women in rural areas who have high level of participation both in professional life and in social-cultural life are neglected. In this regard, "women farmers contest" programme is important to promote the status of women in the social relations system, to accomplish high participation in economic life rural areas and to create women leaders.

\section{Material and Methodology}

Due to socio-cultural factors or gender roles, which are shaped according to gender-based division of labour, women are considered responsible for housework and childcare. Domestic responsibilities prevent women from participating in labour force or in short working. It is expected that women must be first a housewife-mother. Women participate in agricultural production as unpaid family labour force resulted from mentality which sees agricultural production as an extension or another form of housework. Any activity that aims capacity building, active roles in social relations system for women in rural areas and especially those who participate in agricultural production is important. Because it will accomplish that women in agricultural production, who are almost half of the women labour force, will participate in this process in a productive manner and also their social status will be promoted. In this regard, "Women Farmers Contest, which has been organised by the Republic of Turkey Ministry of Food, Agriculture and Livestock since 2004, is important (4). The competition, which aims to improve women farmers' knowledge, enables women to participate in social life at higher level, raises self-confidence, acts like a mediator to increase their participation in knowledge, technology, communication and marketing process of agricultural production. The aims of this competition ca be summarised as follows;

- to evaluate the knowledge of women farmers,

- to assess the outcomes of training-publications for these women,

- to evaluate performance of women farmers,

- to raise self-confidence of these women,

- to raise consciousness of healthy nutrition and producing high quality crop,

- to create and increase women entrepreneurship even if indirectly.

The competition took place among women farmers based in the rural areas of 81 cities in Turkey in the period 2004-2013. Women participated in the competition as a group of 2 people. Those who became "Champions" participated in final competitions organised in 9 Agriculture Regions. Those who became "Champions" participated in Turkey final. "Women Farmers Contest", which is a knowledge competition, generates huge excitement and creates competition environment among women, who participated in the competition in cities and regions, and their families. In the final phase of the city, region and Turkey Competitions, there were questions about plant production, animal breeding, agricultural mechanisation, nutrition, child development, agricultural enterprise, agricultural organisation, the management of family ownership and handcrafts. The questions were selected from question bank/database for university entrance exam.

Self-confidence and ability of expression of these women raised with the "Women Farmers Contest" programme. Moreover, women's knowledge, ability of dealing with agricultural activities and family economy increased and the quality of their participation in labour force changed in a positive manner. This competition was determined as number one or champion among 2000 social events by National Olympics Committee in 2005.

The main material of this research is the Regional champions of "Women Farmers Contest", which have been organised since 2004, and "question forms" which have been applied to women in Turkey finals. In addition, there were some observation activities for qualitative assessments and there were attempts to get an idea about women's behaviour, opinions after the competition. The population of this research is women who participated in Turkey finals since 2004. Accordingly, 127 women, who participated in Turkey finals from 2004 to 2012, were included in this research. In this study "complete count" method was applied yet I reached 61 of these women in the research period. I could not reach other women for several reasons such as moving to another city, marriage, relocation, changing job etc. There were one-to-one interviews with 61 of these women. There are 44 different cities that these women participated in the competition.

Personal interview survey method was applied to these women in their living areas (village, town and district). In addition to this survey method, there was an aim to observe these women's living areas. Statistical software programme 
were used to analyse data obtained through the survey. Frequency distribution was calculated and relations among some variables were examined. There was a focus particularly on changes in women's working and living conditions before and after the competition and their future plans at this stage.

\section{Findings}

The majority of contestants, 95.1\% (N=61), live in villages-towns and came from these places when they participated in contest. $62.3 \%$ of women are under 40 years old. In fact, it is what the contest predicted. Mostly young and educated groups participated in since it was a knowledge competition.

Table 1. Age Distribution

\begin{tabular}{|c|c|c|}
\hline Age Groups & Number & \% \\
\hline $21-30$ & 20 & 32,8 \\
\hline $31-40$ & 18 & 29,5 \\
\hline $41-50$ & 18 & 29,5 \\
\hline $51-60$ & 5 & 8,2 \\
\hline TOTAL & $\mathbf{6 1}$ & $\mathbf{1 0 0 , 0}$ \\
\hline
\end{tabular}

$73.8 \%$ women are married, $19.7 \%$ women are single, and $6.6 \%$ women are widow. It is seen that the majority of contestants are married. Reason for this high percentage of married women is that women could participate in competitions as a group of 2 people. Married women preferred to have another married partner.

Level of education is important for their individual capacity of accomplishment, participation in competition, and the activation of farming potentiality. As it seen in the Table. 2 a significant part of these women, $41.0 \%$, are high school graduates. On the other hand, $37.7 \%$ of them are primary school graduates.

Table 2. Education Distribution

\begin{tabular}{|c|c|c|}
\hline Education Level & Number & $\mathbf{\%}$ \\
\hline Primary School & 23 & 37,7 \\
\hline Secondary School & 8 & 13,1 \\
\hline High School & 25 & 41,0 \\
\hline University & 5 & 8,2 \\
\hline TOTAL & 61 & 100,0 \\
\hline
\end{tabular}

$26.2 \%$ of women identify themselves as housewives. $49.2 \%$ of them described themselves as farmers.

As regards to their professional profile, $60.7 \%$ of these women are farmers, 9.8 are public servants, and 6.6 are workers. $49.0 \%(n=49)$ of working women state that they work for 10 to 12 months in a year. While 79.6 of these women work in their village-towns, the rest works in districts, cities. This fact reveals an interesting point; while $4.9 \%$ of these women state that they are living in districts or cities,
$20.4 \%$ of these women work in districts, cities. This means that women go to district, cities to work on daily basis.

$50.8 \%$ of these women have a family $3-4$ people, $8.2 \%$ of them have a family of $6-7$ people. $4.9 \%$ of these women live alone.

The majority of married women, $63.3 \%(n=41)$, married at 20 or even younger. This fact is interesting how these women take responsibilities and participate in economic life while they are young. $34.5 \%$ of the families of these women have no land while the rest has land with different sizes. $50.8 \%$ (31) of these women note that they have tractors and $49.2 \%$ of them note they do not. 21 out of $31(67.7 \%)$, who noted they had tractors, state that they drive tractors. Considering all women in this research, this percentage is equal to $(21 / 61)$ $34.4 \%$ and it is accepted as a good percentage in rural. This fact reveals that in fact women can easily adopt new things, changes.

As the Table. 3 shows that $44.9 \%$ of working women work either as family labour force or unpaid workers. All of these women work in agriculture sector.

Table 3. Salary/Income Situation of Working Women

\begin{tabular}{|c|c|c|}
\hline Salary/Income & Number $(\mathbf{n}=\mathbf{4 9 )}$ & $\mathbf{\%}$ \\
\hline Monthly Salary & 8 & 16,3 \\
\hline $\begin{array}{c}\text { Wageworkers based on monthly } \\
\text { payment }\end{array}$ & 5 & 10,2 \\
\hline Annual income & 14 & 28,6 \\
\hline Family labour force-unpaid workers & 22 & 44,9 \\
\hline TOTAL & 49 & 100,0 \\
\hline
\end{tabular}

Even women from rural areas work and earn money they usually spend this money for their children and/or families rather than personal needs. In fact, this study has a similar outcome. $66.7 / \%$ women spend their income/wages for their children, families (Table 4).

Table 4. How Do These Women Spend Their Income/Salary

\begin{tabular}{|c|c|c|}
\hline Spending Ways & Number $(\mathbf{n}=\mathbf{2 7})$ & $\mathbf{\%}$ \\
\hline For herself & 9 & 33,3 \\
\hline For children, family & 18 & 66,7 \\
\hline TOTAL & 27 & 100,0 \\
\hline
\end{tabular}

Table 5. Social Security Institution Distribution

\begin{tabular}{|c|c|c|}
\hline Name of Social Security Institutions & $\begin{array}{c}\text { Number } \\
(\mathbf{n = 4 9 )}\end{array}$ & $\mathbf{\%}$ \\
\hline None & 8 & 16,3 \\
\hline $\begin{array}{c}\text { Social Security Institution for Craftsmen, } \\
\text { Artisans and the Self- Employed (directly } \\
\text { and individually) }\end{array}$ & 3 & 6,1 \\
\hline $\begin{array}{c}\text { Social Insurance Institution (directly and } \\
\text { individually) }\end{array}$ & 7 & 14,3 \\
\hline $\begin{array}{c}\text { Social Security Institution for Craftsmen, } \\
\text { Artisans and the Self- Employed } \\
\text { (Agriculture and through her father) }\end{array}$ & 2 & 4,1 \\
\hline Public Servants-Pension Fund Institution & 7 & 14,3 \\
\hline Through her husband & 22 & 44,9 \\
\hline TOTAL & 49 & 100,0 \\
\hline
\end{tabular}


As the Table. 5 shows that only $20.4 \%$ of the working women are directly and individually registered with Social Security Institution for Craftsmen, Artisans and the SelfEmployed or Social Insurance Institution while $14.3 \%$ of them are registered with "Pension Fund Institution". 44.9\% of these women are registered with these institutions through their husbands and $4.1 \%$ of them through their fathers.

\section{How do these women learn the competition?}

Information sources competition affects the number of participants. The main information source of competition for women is, naturally, Provincial/District Directorates of Food, Agriculture and Livestock (47.6\%).

Learning the competition is important yet there is another and more important issue: How do these women decide to participate in the competition. Table. 6 indicates that only $21.4 \%$ of these women made their own decisions and with self-confidence that they would participate in the competition.

Table 6. How do these women decide to participate in the competition?

\begin{tabular}{|c|c|c|}
\hline How do they decide? & Number & $\mathbf{\%}$ \\
\hline $\begin{array}{c}\text { Provincial/District Directorates of Food, } \\
\text { Agriculture and Livestock persuade }\end{array}$ & 18 & 29,5 \\
\hline Self-decision, self-confidence & 13 & 21,4 \\
\hline Husband insists, persuades & 7 & 11,5 \\
\hline Family insists & 7 & 11,5 \\
\hline Former contestants insist & 6 & 9,8 \\
\hline $\begin{array}{c}\text { TAR-GEL [Agricultural Publication } \\
\text { Development] Staff persuade }\end{array}$ & 4 & 6,5 \\
\hline Head of village insists & 3 & 4,9 \\
\hline Close friend insists & 3 & 4,9 \\
\hline TOTAL & 61 & 100,0 \\
\hline
\end{tabular}

As it is seen in the Table.7, those who help women most are Provincial/District Directorates and personals of Food, Agriculture and Livestock staff. Then, husbands have 26.2\%. Having high rate of husbands is important for gaining self-confidence, being an entrepreneur and opening to outside world.

Table 7. Those who help women most during competition period

\begin{tabular}{|c|c|c|}
\hline Preparation Methods & Number* & $\mathbf{\%}$ \\
\hline $\begin{array}{c}\text { Provincial/District Directorates and } \\
\text { personals of Food, Agriculture and Livestock } \\
\text { staff }\end{array}$ & 39 & 63,9 \\
\hline Husbands & 16 & 26,2 \\
\hline Whole family & 13 & 21,4 \\
\hline $\begin{array}{c}\text { TAR-GEL [Agricultural Publication } \\
\text { Development] Staff }\end{array}$ & 13 & 21,4 \\
\hline Village-Town People & 11 & 18,0 \\
\hline Close Friends & 8 & 13,1 \\
\hline Former contestants & 6 & 9,8 \\
\hline None & 4 & 6,5 \\
\hline
\end{tabular}

*: Total number is higher than 61 because women gave more than one answer.

\subsection{The Competition's Contributions to Women's Self-Confidence and Family Relations}

One of the most important outcomes of the "Women Farmers Contest" is contribution to "self-confidence and family relations". As the Table 8 shows, women indicate that the most important contribution of the competition as regards to self-confidence and family relations is that "irreplaceable, indispensable and determination position in family". In this regard, 44 out of 61 women say that my irreplaceable, indispensable and determination position in family "increased". Moreover, 39 of the contestants say after competition "my ability and confidence to solve problems by myself", 34 of them "my neighbours respect", 33 of them "my happiness with work at home and outside" "increased". The competition has an important result for "married" women. As it can be seen from the Table, 36 out of 49 say "she has self-confidence to survive without help from someone else" and 24 out of 49 said "her contribution to child(ren)'s education and life" "increased".

Table 8. Competition's Contributions to Women's Self-Confidence and Family Relations

\begin{tabular}{|c|c|c|c|c|}
\hline Contribution level & Increased & No Change & Decreased & TOTAL \\
\hline irreplaceable, indispensable/determination position in family & 44 & 17 & & 61 \\
\hline Ability and self-confidence to solve problem by myself & 39 & 22 & & 61 \\
\hline self-confidence to survive without help from someone else (for married contestants) & 36 & 13 & & $\mathrm{n}=49$ \\
\hline Neighbours' respect after competition & 34 & 26 & 1 & 61 \\
\hline Happiness with work at home and outside & 33 & 28 & & 61 \\
\hline Competition's contribution to individual and family life style & 32 & 29 & & 61 \\
\hline Making decisions about family expenditure & 29 & 32 & & 61 \\
\hline Support from family to work outside & 26 & 35 & & 61 \\
\hline Competition's contribution to increase in individual and/or family income & 24 & 37 & & 61 \\
\hline Level of contribution to child(ren)'s education and life (for married contestants) & 24 & 25 & & $\mathrm{n}=49$ \\
\hline Joining decision making process and control over family wealth/properties & 17 & 44 & & 61 \\
\hline Income level comparing to before competition & 15 & 46 & & 61 \\
\hline
\end{tabular}


Table 9. Change in the Status of Women as Regards to Decision Making Processes in Family after the Competition

\begin{tabular}{|c|c|c|c|c|c|}
\hline Decision Making Topic & Increased & $\begin{array}{c}\text { Increased } \\
\text { (Limited) }\end{array}$ & No Change & Decreased & TOTAL \\
\hline Using family savings & 9 & 13 & 39 & 61 \\
\hline Working outside home & 9 & 9 & 43 & & 61 \\
\hline Buying Furniture & 7 & 9 & 45 & & 61 \\
\hline Visiting a Doctor & 6 & 4 & 50 & 1 & 61 \\
\hline Buying goods/property & 5 & 5 & 49 & 2 & 61 \\
\hline
\end{tabular}

Table 10. Change in the Status of Women: Before and After the Competition

\begin{tabular}{|c|c|c|c|c|c|c|}
\hline \multirow{2}{*}{ Questions } & \multicolumn{3}{|c|}{ Before the Competition } & \multicolumn{3}{|c|}{ After the Competition } \\
\hline & Yes & No & TOTAL & Yes & No & TOTAL \\
\hline \multicolumn{7}{|c|}{ Social Status } \\
\hline Do other women ask your opinion on agricultural issues? & 23 & 33 & $\mathrm{n}=56$ & 43 & 11 & $\mathrm{n}=54$ \\
\hline Do other women benefit from your experience? & 22 & 39 & 61 & 48 & 13 & 61 \\
\hline Do you have any property? & 11 & 50 & 61 & 11 & 50 & 61 \\
\hline Are member of any cooperative or producer union? & 10 & 51 & 61 & 16 & 45 & 61 \\
\hline \multicolumn{7}{|c|}{ Economic Status } \\
\hline Is your income equal to your expenditure? & 37 & 24 & 61 & 39 & 22 & 61 \\
\hline $\begin{array}{l}\text { Do you decide how to spend family income? Or do you } \\
\text { effectively join decision making process in your family? }\end{array}$ & 36 & 25 & 61 & 52 & 9 & 61 \\
\hline Do you sell what you produce by yourself? & 20 & 36 & $\mathrm{n}=56$ & 27 & 27 & $\mathrm{n}=54$ \\
\hline Do you benefit from agricultural support? & 14 & 42 & $\mathrm{n}=56$ & 32 & 22 & $\mathrm{n}=54$ \\
\hline \multicolumn{7}{|c|}{ Professional life (including agricultural activities) status } \\
\hline $\begin{array}{l}\text { Do you use tools and equipment which are necessary for your } \\
\text { work? }\end{array}$ & 35 & 26 & 61 & 38 & 23 & 61 \\
\hline $\begin{array}{l}\text { Do your family members ask your opinion on agricultural } \\
\text { product to plant? }\end{array}$ & 32 & 24 & $\mathrm{n}=56$ & 42 & 12 & $\mathrm{n}=54$ \\
\hline $\begin{array}{l}\text { When you need, do you apply to relevant agricultural } \\
\text { organisations and institutions? }\end{array}$ & 30 & 31 & 61 & 45 & 16 & 61 \\
\hline Can you follow agricultural developments? & 27 & 34 & 61 & 46 & 15 & 61 \\
\hline $\begin{array}{l}\text { Do your family members ask your opinion on agricultural } \\
\text { work? }\end{array}$ & 25 & 31 & $\mathrm{n}=56$ & 41 & 13 & $\mathrm{n}=54$ \\
\hline Do you have support from experts for your work? & 19 & 42 & 61 & 36 & 25 & 61 \\
\hline Did you talk to experts to improve your work? & 17 & 44 & 61 & 31 & 30 & 61 \\
\hline $\begin{array}{l}\text { When your family member buy new tools and equipment, do } \\
\text { they ask your opinion? }\end{array}$ & 17 & 39 & $\mathrm{n}=56$ & 37 & 17 & $\mathrm{n}=54$ \\
\hline $\begin{array}{l}\text { Did you receive any training/certificate programme for your } \\
\text { work? }\end{array}$ & 13 & 48 & 61 & 22 & 39 & 61 \\
\hline
\end{tabular}

Although the competition contributed to women's self-confidence and family relations, its influence on joining decision making process in family is not at the same level. It is also related to male-dominant family structure, feudal social relations in rural areas. The competition contributed to women's self-confidence and family relations yet same contribution is not observed as regards to "decision making". As it can be seen from the Table 9, change in women's joining decision making processes in family is limited. Women's joining decision making in family is observed and even there is an increase though it is limited in the following issues: using family savings, working outside home, buying furniture, visiting a doctor, and buying goods/property. It should be noted that buying goods/property is at low level. In other words, often women do not join economic decision making processes. Yet, if they join-as it is stated above-they usually work as unpaid family labour force in professional life.

As it is seen from Table 10; there are important changes in women's statutes before and after the competition. There are changes in all statutes related to social, economic and professional life. Women are consulted about economic, 
social issues much more than past. Similarly, they can join decision making processes much more than the past. These facts show that although there is a conservative society structure in the rural areas of Turkey, they can join productive and social relations especially if they are allowed. On the other hand, as it is shown in the Table 11; women have generally opinion thoughts about the competition. Women state that they start to join works, follow technology related to their works and participate in activities in their living areas much more than past.

Table 11. Women's Opinion on the Competition

\begin{tabular}{|c|c|c|c|c|}
\hline Opinions & Agree & $\begin{array}{c}\text { No } \\
\text { comment }\end{array}$ & Disagree & TOTAL \\
\hline $\begin{array}{c}\text { After competition, I } \\
\text { follow } \\
\text { developments } \\
\text { related to my work. }\end{array}$ & 40 & 7 & 14 & 61 \\
\hline $\begin{array}{c}\text { After competition, } \\
\text { my participation in } \\
\text { activities in village, } \\
\text { town, district etc. } \\
\text { increased. }\end{array}$ & 39 & 2 & 20 & 61 \\
\hline $\begin{array}{c}\text { After competition, } \\
\text { my expectations of } \\
\text { my work increased. }\end{array}$ & 37 & 5 & 19 & 61 \\
\hline $\begin{array}{c}\text { After competition, I } \\
\text { work harder to } \\
\text { improve my work. }\end{array}$ & 33 & 5 & 23 & 61 \\
\hline $\begin{array}{c}\text { After competition, I } \\
\text { need to spare more } \\
\text { time for my work. }\end{array}$ & 25 & 14 & 22 & 61 \\
\hline
\end{tabular}

As it can be seen from the Table 12, women state that there is a development and/or an increase in their self-confidence, knowledge-good manners, consciousness, social circle, recognition level etc. while its level is different.

Table 12. Change in Women's lives after the Competition

\begin{tabular}{|c|c|c|}
\hline Changes & Number* & $\%$ \\
\hline Raising self-confidence & 32 & 52,4 \\
\hline Development of knowledge-good manners & 27 & 44,2 \\
\hline Raising consciousness & 22 & 36,0 \\
\hline People ask for advice & 21 & 34,4 \\
\hline Development of social circle & 16 & 26,2 \\
\hline Increase in recognition level & 14 & 22,9 \\
\hline Increase in respectability & 13 & 21,3 \\
\hline $\begin{array}{c}\text { Those who finish secondary and high school } \\
\text { through distance education }\end{array}$ & 7 & 11,4 \\
\hline Change in perspective on life & 6 & 9,8 \\
\hline Increase in communication skills & 6 & 9,8 \\
\hline Those who find a new job & 4 & 6,5 \\
\hline Those who have a new child & 3 & 4,9 \\
\hline $\begin{array}{c}\text { Those who publish article or receive an } \\
\text { invitation to write an article }\end{array}$ & 2 & 3,2 \\
\hline Those who start university & 2 & 3,2 \\
\hline Those who say nothing has changed & 9 & 14,7 \\
\hline
\end{tabular}

*: Total number is higher than 61 because women gave more than one answer.
Only 4 women (6.6\%) expressed that they had some difficulties after the competition. These difficulties are as follows: they started some initiatives yet they received no support. Moreover, 2 women said that they had problems since they could not cover the travel cost for the competition. According to the women; the competition makes contributions to raise self-confidence, to have more respectability, to increase the level of their knowledge, to increase their participation in social circles, to increase solidarity-organising etc. in their social lives (Table 13). $13.1 \%$ of women say it made no contribution to our lives. Another important outcome, which can be seen in the table, is that $(21.3 \%)$ women, though they are a few, say the competition makes contributions to "the problem solving, analysis skills." In fact, it is expected that this percentage would be higher. Because, women with higher self-confidence are expected to be on the front line for problem solving. This low level results from the determining factor of social values and social structure.

Table 13. Competitions' Contribution Forms to Women's Participation in Social Life

\begin{tabular}{|c|c|c|}
\hline Opinions & Number* & $\mathbf{\%}$ \\
\hline Raising women's self-confidence & 39 & 63,9 \\
\hline More respectability in family & 24 & 39,3 \\
\hline Increasing knowledge & 21 & 34,4 \\
\hline Increase participation in social environment & 20 & 32,7 \\
\hline Improving social circles & 19 & 31,1 \\
\hline $\begin{array}{c}\text { Learning new cultures, visiting different } \\
\text { places }\end{array}$ & 18 & 29,5 \\
\hline $\begin{array}{c}\text { Increase in solidarity and organising among } \\
\text { women }\end{array}$ & 17 & 27,8 \\
\hline $\begin{array}{c}\text { Improving entrepreneurship skills and } \\
\text { self-confidence }\end{array}$ & 16 & 26,2 \\
\hline Raising awareness & 16 & 26,2 \\
\hline Increase in wish for learning, reading & 16 & 26,2 \\
\hline Increase in problem solving, analysis skills & 13 & 21,3 \\
\hline No contribution & 8 & 13,1 \\
\hline
\end{tabular}

*: Total number is higher than 61 because women gave more than one answer.

\section{Women's Empathy Skills and Inclinations}

Discovering women's empathy skills is important to discover women's imagination. In this regard, the following question was asked to women: "if you were a high rank bureaucrat or a Minister, what would you do for women work in agriculture?" Women stated that they would deal with first social security, education, employment and loan problem (Table.14). 
Table 14. If women were a powerful figure such as a district governor, a governor, a minister, what would they do for women work in agriculture?

\begin{tabular}{|c|c|c|}
\hline They want to & Number* & \% \\
\hline Provide social security & 23 & 37,7 \\
\hline Provide education & 17 & 27,8 \\
\hline $\begin{array}{c}\text { Begin business, provide employment } \\
\text { opportunity }\end{array}$ & 16 & 26,2 \\
\hline Provide loan & 11 & 18,0 \\
\hline Open courses & 8 & 13,1 \\
\hline Contribute to women organising activities & 8 & 13,1 \\
\hline Establish factory & 6 & 9,8 \\
\hline Provide education, begin business & 6 & 9,8 \\
\hline Prevent violence against women & 6 & 9,8 \\
\hline Create marketing environment for productions & 4 & 6,5 \\
\hline Abolish male dominancy & 4 & 6,5 \\
\hline Provide more technology & 4 & 6,5 \\
\hline Enable women to have properties & 4 & 6,5 \\
\hline Open shelters, social facilities & 3 & 4,9 \\
\hline I do not know & 3 & 4,9 \\
\hline
\end{tabular}

*: Total number is higher than 61 because women gave more than one answer.

\section{Women's Opinion on Problems That Women, Including Themselves, Face and Their Imagination}

Women may have different problems related to their work, families or social and daily lives. In fact, solution for these problems may increase their participation in socio-economic and cultural life. In this regard, competitions are a positive tool to contribute to these issues. Women in this research highlight lack of financial possibility, education, self-confidence, social security and unemployment as the most serious and important problems in their locations (Table.15). 6.5\% women said there was "no problem" in their locations.

Table 15. The most serious problems in their locations

\begin{tabular}{|c|c|c|}
\hline Problems & Number & \% \\
\hline Lack of financial possibility & 21 & 34,4 \\
\hline Lack of education & 18 & 29,5 \\
\hline Lack of self-confidence & 15 & 24,5 \\
\hline Lack of social security & 17 & 27,8 \\
\hline Difficulty of finding a job, unemployment & 13 & 21,3 \\
\hline Heavy workloads & 13 & 21,3 \\
\hline Lack of interest from public & 11 & 18,0 \\
\hline organisations/institutions & 9 & 14,7 \\
\hline Lack of vocational education & 7 & 11,4 \\
\hline No organisation, disorganisation & 7 & 11,4 \\
\hline Men's pressure and/or indifference & 7 & 11,4 \\
\hline Gender discrimination & 7 & 11,4 \\
\hline Domestic violence & 6 & 9,8 \\
\hline Underage marriage & 4 & 6,5 \\
\hline Limited marketing opportunities & 4 & 6,5 \\
\hline Nothing & & 13 \\
\hline
\end{tabular}

*: Total number is higher than 61 because women gave more than one answer.
Women's dreams about the future are shaped by living conditions that they have. These dreams usually are about something women cannot access or have difficulties in accession to them. As it can be seen from the Table 16., women's dreams include education for their children, having social security measures. These outcomes are interesting also about problems that women face most in their lives.

Table 16. Women's Imagination for Future

\begin{tabular}{|c|c|c|}
\hline Imagination & Number* & \% \\
\hline $\begin{array}{c}\text { Children attend education and have a } \\
\text { profession }\end{array}$ & 26 & 42,6 \\
\hline Having social security & 14 & 22,9 \\
\hline Being rich & 13 & 21,3 \\
\hline Being a businesswoman & 11 & 18,0 \\
\hline Having a house & 11 & 18,0 \\
\hline Having a big farmer & 11 & 18,0 \\
\hline Increasing the capacity of work & 9 & 14,7 \\
\hline Having a job & 8 & 13,1 \\
\hline Better life & 7 & 11,4 \\
\hline Retirement & 5 & 8,1 \\
\hline Being a public servant & 4 & 6,5 \\
\hline Covering children's marriage \\
expenses & 4 & 6,5 \\
\hline Going to pilgrimage & 4 & 6,5 \\
\hline Completing education & 3 & 4,9 \\
\hline Nothing & 3 & 4,9 \\
\hline
\end{tabular}

*: Total number is higher than 61 because women gave more than one answer.

\subsection{Stories from the Competition}

Oya BADAN, from Kars Province, One of the Turkey Finalists in 2004

"I deal with goose breeding. I have 20 geese. I sell 40 geese ever year. I sold one goose for 60 TL (Turkish Lira) last year and I spent its income by myself and for my children. I deal with everything related to geese. I can drive tractor and deal with cattle. I can deal with goose breeding in partnership with other women in village and in fact I can be leader for this work. If state provides more support, I want to expand my business. Women Farmers Contest made many contributions to my life. My self-confidence and knowledge raised. After I became successful in the competition, the number of women who want to participate increased as well. After the competition I bought a deep freeze for geese. I send my geese to İstanbul and Ankara. Now, women in village respect me more than past, they come to me and ask my advice or opinion."

Mine ÖZYÖN, from Kirıkkale Province, One of the Turkey Finalists in 2006

"Competition raised my knowledge and self-confidence. I deal with greenhouse cultivation with my close friends in 
village. I attended course for greenhouse cultivation. Of course, this greenhouse cultivation activity should be supported. I once again participated in the competition in 2012. My project was on greenhouse cultivation. Provincial Directorate of Food, Agriculture and Livestock supported me. I thank the Provincial Directorate for its support. Now, I have my own greenhouse cultivation. With my greenhouse cultivation, I will be an example for my circles. Furthermore, I attended Workshop on Women in National Rural Areas and I admired it."

Zeynep AYTAR, from Antalya Province, One of the Turkey Finalists in 2006

"I think competition is very good and useful. The competition raised my knowledge and self-confidence. I used to work at other places since we have no land. I work as agriculture worker for about 45 to 60 days. No one called or followed up after the competition and it made me sorry. If they had followed up, we could have done a very good job and become an example for our circles."

Serpil KABAY, from Burdur Province, One of the Turkey Finalists in 2010

"My husband persuaded me to participate in competition. My mother-in-law saw the competition poster, she and my husband informed me about it and suggested me to participate, and she said "you could do it". My husband supported this suggestion very strongly and I participated. I became number 4 in all over Turkey. Men in village had a positive attitude toward our participation in the competition and they supported. We became admirable women in the village, our knowledge raised. I can drive tractor. If a chance is given, we can do better projects, jobs."

Birgül SARI, from Antalya Province, One of the Turkey Finalists in 2010

"I have a position of "leader woman" in village. I am interested in agriculture, knowledge and education a lot. We established a training centre for women in the village. We conduct agricultural training for women. I deal with greenhouse cultivation. My greenhouse was shown as an example and rewarded with "blue flag". If we, as women in this area, have chance we want to have joint entrepreneurship as for greenhouse cultivation, marketing, jam and canned foods. I attended all training-publication activities organised by Provincial Directorate of Food, Agriculture and Livestock. I have many certificates. I prepared for the competition with the contribution of staff from the Provincial Directorate of Food, Agriculture and Livestock. My husband supported and empathised with me throughout the competition. After the competition, my circles' interest increased."

\section{Conclusions and Main Inferences}

Women want to be in every field and to participate in these fields much more than they do now. Important point of this participation is being an active, efficient and perpetual one. The problems of almost half of women, who perform a significant part of agricultural production and are part of employees in this sector, expect attention and solution.

If we want to have women as individuals with self-confidence and productive this expectation or fact should be considered as their deserved value. Any activity, practices are important for women to make them an important actor of social life, enable them to stand on their own feet or to survive without help/support from someone else, help them to raise self-confidence.

In this regard, "Women Farmers Contest" organised by the Republic of Turkey Ministry of Food, Agriculture and Livestock has become an important turning point for women in rural areas. There different gains for women and their perspective on future change in competition. Women's expectations increase and this increase lead to diversification of economic, social and cultural activities that they want to do.

When Women Farmers Contest is assessed in a holistic manner, the external effects of the competition are higher, more important than dealing with, analysing competitors one by one. Because, this competition made an impact and activated, forced public opinion to act at least for some issues, was reported in visual and written media, increased women's expectations and maybe the most importantly, revealed the importance of women in agriculture, rural.

"Women Farmers Contest" is a well-established competition that has become a tradition in Turkey. The competition made many contributions to women in terms of social, economic, cultural and political aspects.

The competition is important in terms of building women's entrepreneurship capacity, increasing their rate in employment and contribution to employment, strengthening social relations. Given that women gentlemanly contested, it is a not a coincidence that this was determined as number one or champion among 2000 social events by National Olympics Committee.

\section{REFERENCES}

[1] Gülçubuk,B.-Yasan,Z., "İşsizlik Yoksulluk Göç Kıskacında Kırsal Alanda Kadın Emeği".Uluslararası Multidisipliner Kadın Kongresi, 13-16.Ekim.2009, İzmir-TURKEY.

[2] www.tuik.gov.tr

[3] Arıkan, G. 1988. "Kırsal Kesimde Kadın Olmak." Hacettepe Üniversitesi Edebiyat Fakültesi Dergisi, Cilt: 5, Sayı: 2, Ankara, 1-16.

[4] Gülçubuk, B. Kadın Çiftçiler Yarışıyor-Etki Değerlendirme Araştırması. Ankara Üniversitesi-AKÇAM, Gıda Tarım ve Hayvancılık Bakanlığı, Ankara, 2012.

[5] Gülçubuk,B., "The Dimensions of Women's Contribution to the Workforce in Agriculture: the Turkey Case". Inter. Business and Economic Research Journal, Volume 9, Number 5, May 2010, USA. 
[6] Gülçubuk,B. ve Diğerleri.,-"Türkiye'de Kırsal Alanda Kadının Girişimciliğini Etkileyen Faktörlerin Belirlenmesi ve Kadınların $\mathrm{Bu}$ Konuda Güçlendirilmesine Yönelik Politika Önerilerinin Geliştirilmesi". TUBITAK, 2011.

[7] Gülçubuk,B., "Tarımsal Üretim ve Kırsal Kalkınma Uğraşılarının Ana Aktörleri: Kadınlar”. GTHB-Türktarım Dergisi. Say1:203, Ocak-Şubat 2012, s:38-47
[8] KSGM., Türkiye'de Kırsal Kesimin Yapısı ve Kadınlar. Başbakanlık Kadının Statüsü ve Sorunları Genel Müdürlüğü Yayınları, Ankara,2000.

[9] Tarım ve Köyișleri Bakanlığı., Kırsal Alanda Kadın Çalıștayı. 15-17. Ekim.2008, Ankara, 2008.

[10] www.tarim.gov.tr 